Article

\title{
Lethal and Sub-Lethal Effects of Insecticides on the Pink Hibiscus Mealybug, Maconellicoccus hirsutus (Hemiptera: Pseudococcidae)
}

\author{
Fatemeh Ganjisaffar*(D), Sharon A. Andreason (D) and Thomas M. Perring \\ Department of Entomology, University of California, 900 University Ave., Riverside, CA 92521, USA; \\ sharon.andreason@ucr.edu (S.A.A.); thomas.perring@ucr.edu (T.M.P.) \\ * Correspondence: fatemeh.ganjisaffar@email.ucr.edu; Tel.: +1-951-827-4518
}

Received: 11 December 2018; Accepted: 11 January 2019; Published: 16 January 2019

\begin{abstract}
The pink hibiscus mealybug, Maconellicoccus hirsutus (Green) (Hemiptera: Pseudococcidae) is a pest of many plants, and a new problem on dates in California. The effects of seven insecticides and water on different life stages of this mealybug were studied to identify the best material for control. Water did not have any significant effect on mealybugs, but the insecticide treatments significantly affected all life stages tested. The egg hatch rate ranged from $28.5 \%$ to $17.2 \%$ for spirotetramat, bifenthrin, flupyradifurone, fenpropathrin, and buprofezin treatments, and was lower for sulfoxaflor $(2.8 \%)$ and acetamiprid $(0.1 \%)$. Despite high survival of neonate crawlers in the non-treated control and water treatments, $53.1 \%$ and $34.6 \%$ survived in the spirotetramat and buprofezin treatments, respectively; survival was zero in the other treatments. Spirotetramat and buprofezin caused very low mortality of nymphs in the first day post-treatment, but mortality significantly increased over time and reached $42.8 \%$ and $50.6 \%$ by day 6 , respectively. The other treatments were highly toxic to the nymphs (79.4-99.4\% on day 6). Insecticides also had a significant effect on the feeding ability of nymphs. By day 6 after treatment, $73.9 \%$ to $100 \%$ of nymphs treated with different insecticides stopped feeding although they were still alive. Insecticides showed no effect on the mortality of adult females, but the percentages of ovipositing females were significantly reduced (51.1\% to $10.6 \%)$ in all insecticide treatments, except buprofezin, which was not statistically different from water and the non-treated control. In the process of our studies, we identified abnormalities in the appearance of eggs from females treated with various insecticides, and these aberrant eggs are described.
\end{abstract}

Keywords: toxicity; feeding disruption; spray bioassay; date palm; synthetic insecticides

\section{Introduction}

The pink hibiscus mealybug (PHM), Maconellicoccus hirsutus (Green) (Hemiptera: Pseudococcidae), is thought to be native to southern Asia as it first was collected and described in India in 1908 [1,2]. The first invasion of the pest was reported from Egypt in 1925 [3]. Since then, it has spread to other tropical, subtropical, and temperate regions of the world including the rest of Africa [4-7], the Middle East [8,9], Australia [10], the Caribbean Islands [11,12], and the Americas [13-18]. In the United States and related territories, PHM first was detected in Hawaii in 1983 [19] and has been established in the Mariana Islands [20], Puerto Rico [13,21], California [22], Florida [23] and the Virgin Islands [24]. In addition, infestations have been reported from Alabama and Oklahoma (2005), Louisiana (2006), New York and Texas (2007), Georgia (2008), North and South Carolina (2009), and Tennessee (2014) according to the National Agricultural Pest Information System (NAPIS) [25].

Pink hibiscus mealybug is a polyphagous sap-sucking insect that feeds on a wide range of host plants in 76 plant families and over 200 genera [26-28]. Economic losses occur in forest trees and 
ornamentals, field crops, vegetables, and fruit trees such as citrus, grapes, and avocados [13,23,29-31]. Feeding damage by PHM results in deformed fruits, leaves, and shoots, stunted plant growth, and eventual plant death [13,32]. The pink hibiscus mealybug is considered a serious pest in the United States, due to its extremely broad range of economically important hosts [33]. Estimated economic losses due to its damage and control have been predicted to reach $\$ 700$ million in the United States [34] and \$5 billion globally [35].

In California, the first introduction of PHM was into the Imperial Valley (Imperial Co., CA, USA) in the fall of 1999. A biological control program by the California Department of Food and Agriculture (CDFA) was established, and two exotic encyrtid parasitoid wasps, Anagyrus kamali Moursi and Gyranusoidea indica Shaffee were released from 2000-2004. This program resulted in the establishment of the parasitoids and reduction of PHM to nearly undetectable levels [36]. Pink hibiscus mealybug was detected further north in the Coachella Valley (Riverside Co., CA, USA) in 2009 and slowly spread northward until 2014 when it was found to be widespread on landscape plants in the urban areas from Indian Wells to Palm Springs. To address this problem, we initiated a biological control program in which we released Anagyrus callidus Triapitsyn, Andreason \& Perring (originally thought to be A. kamali but described as a new species [37]) and G. indica.

In addition to infestations on ornamentals, PHM has been identified in fruit bunches of date palms growing in the Coachella Valley. Although classical biological control has proven to be effective in urban regions of the Imperial and Coachella Valleys, the use of parasitoids in dates is limited. A cultural practice used to prevent insect infestation (especially carob moth, Ectomyelois ceratoniae (Zeller)) and reduce rain damage which can lead to fruit rotting [38], is covering the fruit bunches with polyester mesh bags [39]. These bunch covers also prevent access of natural enemies to pests in the bunches and mealybug populations can build up rapidly in dates that become infested before the bunches are covered (Figure 1). Therefore, the timing of control is critical to ensure bunches are pest free before covering. In addition, it is important to provide date producers with a range of control options from which a holistic management program can be developed. The goal of this study was to evaluate the toxicity of seven insecticides with different modes of action to identify the best candidates for PHM control.
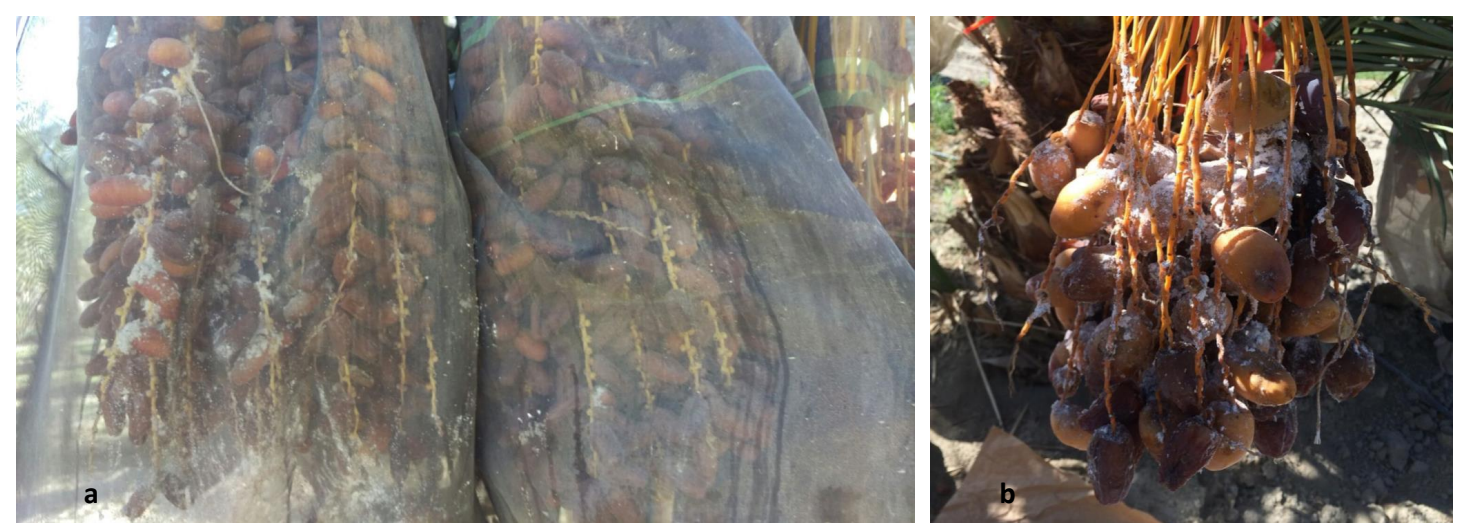

Figure 1. (a) Date bunches (variety Medjool) covered with polyester mesh bags and infested with pink hibiscus mealybug. The covering can limit biological control using parasitoid wasps. (b) A date bunch (variety Medjool) with heavy infestations of pink hibiscus mealybug.

\section{Materials and Methods}

\subsection{Insect Rearing}

Terminal branches of the carob tree (Ceratonia siliqua L.) infested with PHM were collected from the Coachella Valley in the fall of 2015 and transported to the University of California, Riverside (UCR) 
Insectary and Quarantine facility under the appropriate permit. Colonies were started and have been maintained on squash fruit (Cucurbita moschata Duchesne ex Poir., varieties Black Futsu and Shishigatani) grown at the Agricultural Operations at UCR. Harvested squash were washed to remove dirt and any arthropods, decontaminated in a 5\% bleach solution for $5 \mathrm{~min}$, then transferred to a container of water for a few minutes before a final rinse in distilled water to remove bleach residues. The squash fruits were infested with first instar nymphs (crawlers) which were attracted to a pinpoint light within a dark rearing cabinet. The crawlers were sprinkled onto clean squash using a flour sifter every day. Mealybugs infested the squash and were kept in a dark cabinet where they develop into adults. Males and females mated, and their progeny provided a consistent supply of crawlers to re-infest new squash. The PHM colony was maintained at $26 \pm 2{ }^{\circ} \mathrm{C}, 50 \pm 10 \% \mathrm{RH}$, and 0:24 L:D photoperiod.

\subsection{Experimental Arenas}

For experimental arenas, we needed a substrate that could last for about 10 days (duration of the bioassay) allowing us to evaluate the effect of different treatments for 6 days after treatment. Also, it was important that the substrate could support the development of PHM. Date fruits and squash fruits and leaves of some common host plants, Chinese hibiscus (Hibiscus rosa-sinensis L.), squash, and cotton (Gossypium hirsutum L.), were tested for their suitability in experimental arenas. After these preliminary tests, cotton leaves were selected based on the criteria mentioned above. The cotton plants were grown in a greenhouse until they reached a height of 50-60 cm, after which they were moved to the laboratory to make experimental arenas. Arenas consisted of $6 \times 1.5 \mathrm{~cm}$ Petri dishes, containing a substrate of $0.5 \%$ agar (MP Biomedicals, Santa Ana, CA, USA). A cotton leaf disc ( $4 \mathrm{~cm}$ in diameter) was placed with the abaxial side facing up on top of the agar. The $0.5 \%$ agar concentration provided a semi-solid substrate that kept leaves from desiccating. A 1-cm hole was made in the lid of the Petri dish and covered with fine mesh for ventilation while not allowing escape of mealybugs.

\subsection{Insecticides Evaluated and Treatment Methodology}

The materials selected for this bioassay were those used against mealybugs or similar pests in other crops, and they represented a wide range of modes of actions. Insecticides tested were flupyradifurone, spirotetramat, sulfoxaflor, buprofezin, acetamiprid, bifenthrin, and fenpropathrin (Table 1). For each insecticide, the maximum label rate for mealybugs or similar pests on another agricultural commodity was identified, and the concentration of this rate in $935 \mathrm{~L} /$ ha of water was determined (Table 1). Each material was mixed with distilled water using this concentration, placed in the reservoir of a deluxe airbrush (Central Pneumatic \#69492, Camarillo, CA, USA) set at 5 psi and held perpendicular at $15 \mathrm{~cm}$ away from the experimental arenas inhabited by mealybugs. The effect of distilled water also was evaluated, and there was a non-treated control.

Table 1. Insecticides evaluated against pink hibiscus mealybug, Maconellicoccus hirsutus.

\begin{tabular}{|c|c|c|c|c|c|}
\hline Common Name & Trade Name & Chemical Class & Mode of Action a & $\begin{array}{l}\text { Max. Label Rate } \\
\text { mL or } g^{*} \text { AI ha }\end{array}$ & $\begin{array}{c}\text { Bioassay Rate } \\
\mu \mathrm{L} \text { or } \mathrm{g}^{*} \mathrm{AI} \mathrm{mL}^{-1} \text { DI Water }\end{array}$ \\
\hline Spirotetramat & Movento 240 SC ${ }^{\text {c }}$ & Tetramic acid & 23 & 731 & 0.78 \\
\hline Buprofezin & Applaud DF ${ }^{d}$ & Buprofezin & 16 & $1680^{*}$ & $0.00180 *$ \\
\hline Acetamiprid & Assail $70 \mathrm{WP}^{\mathrm{e}}$ & Neonicotinoid & $4 \mathrm{~A}$ & $237^{*}$ & $0.00025^{*}$ \\
\hline Sulfoxaflor & Closer SC $^{\mathrm{d}}$ & Sulfoximine & $4 \mathrm{C}$ & 300 & 0.32 \\
\hline Flupyradifurone & Sivanto Prime ${ }^{c}$ & Butenolide & $4 \mathrm{D}$ & 1023 & 1.09 \\
\hline Bifenthrin & Brigade $2 \mathrm{EC}^{\mathrm{f}}$ & Pyrethroid & 3 & 937 & 1.00 \\
\hline Fenpropathrin & Danitol 2.4 EC g & Pyrethroid & 3 & 1535 & 1.64 \\
\hline
\end{tabular}

${ }^{a}$ Mode of action classification was taken from Insecticide Resistance Action Committee (IRAC) Version 8.3.

${ }^{b}$ Concentrations were based on an application rate of 935 liters/hectare, or 100 US gallons/acre. The asterisk symbol $\left({ }^{*}\right)$ refers to the solid insecticide formulations for which the maximum label rate and the bioassay rate were determined in $\mathrm{g} \mathrm{AI} \mathrm{ha}{ }^{-1} .{ }^{\mathrm{c}}$ Bayer CropScience, Research Triangle Park, NC, USA. ${ }^{\mathrm{d}}$ Dow Agrosciences, Indianapolis, IN, USA. e United Phosphorus, Inc., King of Prussia, PA, USA. ${ }^{\mathrm{f}}$ FMC Corporation, Philadelphia, PA, USA. ${ }^{g}$ Valent U.S.A LLC, Walnut Creek, CA, USA. 


\subsection{Bioassays}

All treatments were evaluated at the same time. After spraying the arenas, the leaves were allowed to dry for about 45 to $60 \mathrm{~min}$ at room temperature, and then the lids were placed on the arenas. All experimental arenas then were maintained in a growth chamber at $24 \pm 2{ }^{\circ} \mathrm{C}, 50 \pm 10 \% \mathrm{RH}$, and 0:24 L:D photoperiod during the evaluation period.

\subsubsection{Eggs}

Gravid females were brushed off the squash in the stock colony; these squash fruits had been infested with crawlers 28 days earlier. Five Petri dishes $(10 \times 1.5 \mathrm{~cm})$ were created with cotton leaves as mentioned previously, and 30 females were transferred to each dish. After 3 days, the ovisacs (waxy filamentous secretions covering eggs) were gently detached from the females using a fine brush, and they were moved individually to experimental arenas. The ovisac in each arena then was sprayed or left as a control. Each treatment was replicated 12 times (twelve arenas per treatment). Following treatments, the ovisacs were pulled apart and the total number of eggs in each ovisac was counted. The eggs were checked daily for the next 12 days. At this time, the numbers of hatched/unhatched eggs and dead/alive crawlers were recorded. A second study was conducted on eggs in which the ovisacs were not pulled apart, allowing the assessment of the treatment to intact ovisacs. For this study, ten ovisacs were placed in each arena and sprayed, after which the effects on egg hatchability and crawler survival were determined. Each treatment was replicated 10 times in this study.

\subsubsection{Nymphs}

Second-instar nymphs were brushed off a 14-day-old infested squash from the stock colony. Twenty nymphs were transferred to each arena, and allowed to settle for $24 \mathrm{~h}$, after which 15 successfully settled individuals were kept in each arena. Each treatment was replicated 12 times. After treatments, mortality was recorded at $24 \mathrm{~h}$ intervals for 6 days. Mealybugs were considered dead if they failed to move their legs after gentle probing with a fine brush. In addition, the number of nymphs that were still alive but stopped feeding (probed mealybugs were unable to grip the leaf and their stylet was not inside the leaf) was recorded daily.

\subsubsection{Adult Females}

Adult females were brushed off a 28-day-old infested squash from the stock colony. Similar to the nymph bioassay, twenty adult females were transferred to each arena from which 15 settled individuals were kept after $24 \mathrm{~h}$. There were 12 replicates for each treatment. Mortality was recorded at $24 \mathrm{~h}$ intervals for 6 days. Mealybugs were considered dead if they failed to move legs after gentle probing with a fine brush. In addition to the mortality assessment, the effect of insecticide treatments on oviposition was determined by recording the proportion of ovipositing females in each arena at day 6 after application.

\subsection{Statistical Analysis}

All data analyses were performed using $R$ version 3.5.1 for windows [40]. A generalized linear model (GLM) with a binary response (dead/alive) and a binomial distribution (glm function) was applied to test the effects of different treatments on mortality of the nymphs and adult females. The GLM was followed by Tukey's test (glht function) to compare the mean mortality rates among different treatments $(p<0.01)$. For the number of nymphs that stopped feeding, the data were analyzed using Fisher's Exact test followed by pairwise comparisons between treatments (cldlist function) $(p<0.01)$. The variances in the percentage of hatched eggs and the percentage of ovipositing females were heterogeneous $(p<0.05)$, therefore they were subjected to one-way ANOVA followed by Games-Howell posthoc test $(p<0.05)$. 


\section{Results}

Insecticide treatments had a significant effect on the average hatch rate of the mealybug eggs $\left(F_{8,98}=76.58, p<0.001\right)$ (Table 2$)$. The highest hatch rates were observed in the non-treated control $(85.7 \%)$ and water $(78.4 \%)$ treatments, which were not statistically different from each other. The hatch rate declined significantly in the insecticide treatments, and was not significantly different between spirotetramat, bifenthrin, flupyradifurone, fenpropathrin, and buprofezin treatments (ranging from $28.5 \%$ to $17.2 \%)$. Sulfoxaflor and acetamiprid treatments showed significantly lower hatch rates $(2.8 \%$ and $0.1 \%$, respectively). A high percentage of crawlers survived after emergence in the non-treated control and water treatments (93.2\% and $82.9 \%$, respectively). Treatments with the two growth regulators, spirotetramat and buprofezin, resulted to $53.1 \%$ and $34.6 \%$ crawler survival, respectively. However, the crawler survival in other treatments was negligible or zero (Table 2). The statistical comparison of the survival rates among the treatments was not possible because only one of the eggs in one of the replicates in the acetamiprid treatment hatched, and there was an insufficient number of replicates to perform the analysis.

Table 2. Effects of different treatments on the mean hatch rate \pm SE of Maconellicoccus hirsutus eggs and the mean survival rate $\pm \mathrm{SE}$ of the emerged crawlers.

\begin{tabular}{lcc}
\hline Treatment & \% Hatched Eggs in Each Ovisac & \% Survived Crawlers after Emergence \\
\hline Non-treated & $85.7 \pm 3.0 \mathrm{a}$ & $93.2 \pm 1.6(12)$ \\
Water & $78.4 \pm 5.2 \mathrm{a}$ & $82.9 \pm 3.3(12)$ \\
Spirotetramat & $28.5 \pm 4.1 \mathrm{~b}$ & $53.1 \pm 9.4(12)$ \\
Bifenthrin & $23.4 \pm 4.1 \mathrm{~b}$ & $0.6 \pm 0.6(12)$ \\
Flupyradifurone & $21.4 \pm 4.5 \mathrm{~b}$ & $0.3 \pm 0.3(12)$ \\
Fenpropathrin & $20.5 \pm 2.3 \mathrm{~b}$ & $0.0(12)$ \\
Buprofezin & $17.2 \pm 3.6 \mathrm{~b}$ & $34.6 \pm 7.8(12)$ \\
Sulfoxaflor & $2.8 \pm 1.0 \mathrm{c}$ & $0.0(7)$ \\
Acetamiprid & $0.1 \pm 0.1 \mathrm{c}$ & $0.0(1)$ \\
\hline
\end{tabular}

ANOVA table summary: $F_{8,98}=76.58, p<0.001$. Values within the same column followed by the same letter are not significantly different, Games-Howell Test $(p<0.05)$. Number of replicates have been given in parentheses. Due to zero hatch rate in acetamiprid-treated eggs, the statistical comparison of the survival rates was not possible.

Observations of treated ovisacs provided additional information about the effects of insecticides on the emerged crawlers (Figure 2). In the non-treated control and water treatments, a high percentage of the eggs hatched, and the crawlers survived normally. In treatments with the growth regulators, spirotetramat and buprofezin, a much lower number of eggs hatched and some of the crawlers survived (Figure 2c,d, respectively). For ovisacs treated with bifenthrin, the eggs hatched but the emerged crawlers were not able to leave the ovisac and died within it (Figure 2e). Crawlers in the fenpropathrin treatment were able to leave the ovisac but died close to it with the chorion still attached to the nymph (Figure 2f). In the flupyradifurone treatment, most of the crawlers could emerge from the egg chorion and leave the ovisac but died close to it (Figure 2g). Sulfoxaflor resulted in the same crawler mortality but a much lower number of eggs hatched. The hatch rate was almost zero in the ovisacs treated with acetamiprid (Figure $2 \mathrm{~h}$ ). 

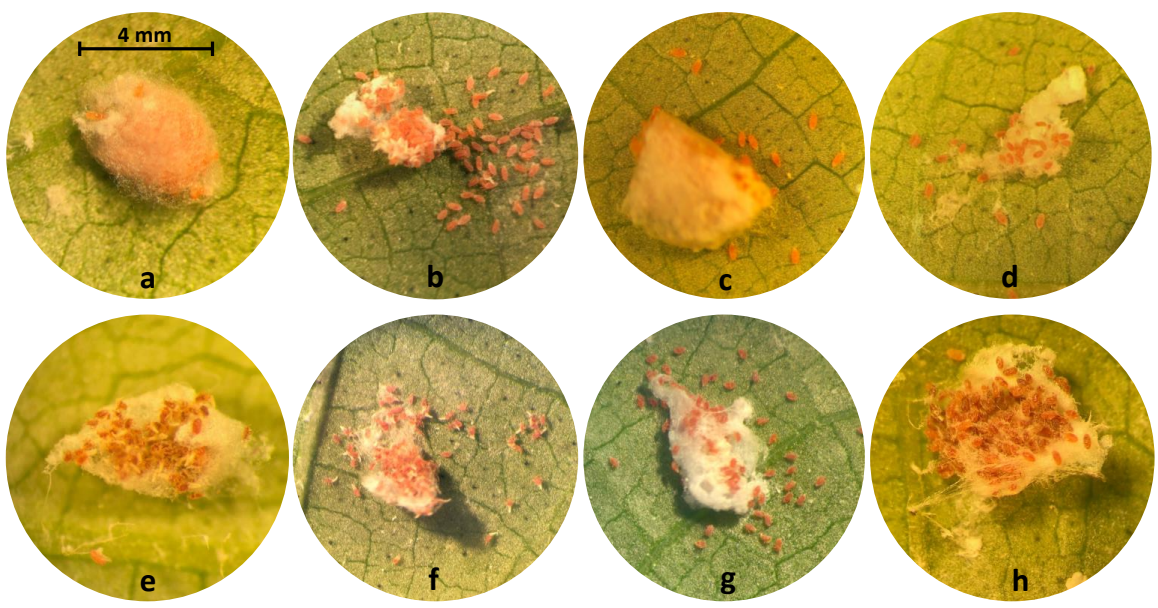

Figure 2. The effects of different treatments on the eggs of Maconellicoccus hirsutus in undisturbed ovisacs and survival of the emerged crawlers after egg hatching: (a) An ovisac before treatment (b) Non-treated control and water: High egg hatchability and survival of crawlers (c) Spirotetramat: Low hatch rate of eggs but medium survival of crawlers (d) Buprofezin: Very low hatch rate of eggs and low survival of crawlers (e) Bifenthrin: Low egg hatch and zero survival of crawlers. Crawlers died within the ovisac. (f) Fenpropathrin: Crawlers were able to leave the ovisac but died shortly close to it with the egg chorion still attached to the nymph. (g) Flupyradifurone: Most of the crawlers could emerge from the egg choroin and leave the ovisac but died shortly close to it. Sulfoxaflor resulted in the same crawler mortality but a much lower number of eggs hatched. (h) Acetamiprid: The hatch rate was almost zero.

Mortality of PHM nymphs was significantly affected by different treatments at all time intervals $(p<0.01)$ (Table 3). Mortality with water was not significantly different from the non-treated control from day 1 to day 6 . Spirotetramat caused low mortality in the first two days $(0.6 \%$ and $8.9 \%)$ which were not statistically different from the non-treated control and water. However, the mortality by this growth regulator increased over time and reached $42.8 \%$ by day 6 (71-fold increase from day 1 to day 6). The other growth regulator, buprofezin, showed a significant difference from the water and non-treated control beginning at day 4, and caused 50.6\% mortality at day 6 (13-fold increase from day 1 to day 6). Mortality with sulfoxaflor increased from $8.9 \%$ on day 1 to $79.4 \%$ on day 6 though it was not significantly different from non-treated control and water in the first day. Acetamiprid, flupyradifurone, fenpropathrin, and bifenthrin were the most toxic insecticides to the mealybug nymphs as indicated by the highest mortality rates from day $1(27.8-60.0 \%)$ to day $6(89.4-99.4 \%)$ (Table 3).

In addition to the acute mortality effects on nymphs, the tested insecticides had a significant impact on the feeding ability $(p<0.01)$ (Table 4$)$. One day after spray treatments, more than $97.3 \%$ of the nymphs treated with sulfoxaflor, acetamiprid, flupyradifurone, fenpropathrin, and bifenthrin stopped feeding although they were still alive. This rate reached $100 \%$ by the second day. For spirotetramat and buprofezin, the percentages of nymphs that stopped feeding increased from $8.3 \%$ on day 1 to $75.6 \%$ and $73.9 \%$, respectively, on day 6 . There were no significant differences between these growth regulators and the other insecticides on days 5 and $6(p<0.01)$ (Table 4$)$. 
Table 3. Effects of different treatments on the mean mortality rate \pm SE of Maconellicoccus hirsutus nymphs and adult females for six days post-treatment.

\begin{tabular}{|c|c|c|c|c|c|c|c|}
\hline Stage Tested & Treatment & \multicolumn{6}{|c|}{$\%$ Mortality } \\
\hline \multirow{6}{*}{ Nymphs } & Non-treated & $0.6 \pm 0.6 \mathrm{a}$ & $1.7 \pm 1.2 \mathrm{a}$ & $4.4 \pm 1.9 \mathrm{a}$ & $8.3 \pm 1.9 \mathrm{a}$ & $10.0 \pm 1.7 \mathrm{a}$ & $12.2 \pm 2.0 \mathrm{a}$ \\
\hline & Spirotetramat & $0.6 \pm 0.6 \mathrm{a}$ & $8.9 \pm 2.5 a, b$ & $18.9 \pm 2.1 \mathrm{~b}$ & $30.6 \pm 1.7 b$ & $39.4 \pm 2.1 b$ & $42.8 \pm 1.9 \mathrm{~b}$ \\
\hline & Buprofezin & $3.9 \pm 1.5 \mathrm{a}$ & $10.0 \pm 2.2 \mathrm{a}, \mathrm{b}$ & $13.3 \pm 2.7 \mathrm{a}, \mathrm{b}$ & $26.1 \pm 2.2 b$ & $38.3 \pm 2.0 \mathrm{~b}$ & $50.6 \pm 2.9 b$ \\
\hline & Sulfoxaflor & $8.9 \pm 1.9 \mathrm{a}$ & $22.8 \pm 2.7 b$ & $38.9 \pm 3.7 \mathrm{c}$ & $61.1 \pm 4.4 \mathrm{c}$ & $72.2 \pm 4.2 \mathrm{c}$ & $79.4 \pm 2.9 c$ \\
\hline & Fenpropathrin & $45.0 \pm 3.1 \mathrm{~b}, \mathrm{c}$ & $60.0 \pm 4.6 \mathrm{c}, \mathrm{d}$ & $78.3 \pm 4.4 \mathrm{~d}, \mathrm{e}$ & $90.0 \pm 2.7 \mathrm{~d}, \mathrm{e}$ & $97.2 \pm 1.3 \mathrm{~d}$ & $98.9 \pm 0.7 \mathrm{~d}$ \\
\hline & Bifenthrin & $47.2 \pm 5.1 \mathrm{c}$ & $70.0 \pm 5.9 \mathrm{~d}$ & $83.3 \pm 5.0 \mathrm{~d}, \mathrm{e}$ & $92.8 \pm 3.1 \mathrm{~d}, \mathrm{e}$ & $98.9 \pm 0.7 \mathrm{~d}$ & $99.4 \pm 0.6 \mathrm{~d}$ \\
\hline \multirow{5}{*}{ Adults (ㅇ) } & Non-treated & $0.0 \mathrm{a}$ & $0.0 \mathrm{a}$ & $0.0 \mathrm{a}$ & $0.0 \mathrm{a}$ & $0.0 \mathrm{a}$ & $0.0 \mathrm{a}$ \\
\hline & Water & $0.0 \mathrm{a}$ & $0.0 \mathrm{a}$ & $0.0 \mathrm{a}$ & $0.0 \mathrm{a}$ & $0.0 \mathrm{a}$ & $0.0 \mathrm{a}$ \\
\hline & Spirotetramat & $0.0 \mathrm{a}$ & $0.0 \mathrm{a}$ & $0.0 \mathrm{a}$ & $0.0 \mathrm{a}$ & $0.0 \mathrm{a}$ & $0.6 \pm 0.6 \mathrm{a}$ \\
\hline & Fenpropathrin & $1.1 \pm 0.7 \mathrm{a}$ & $1.1 \pm 0.7 \mathrm{a}$ & $1.1 \pm 0.7 \mathrm{a}$ & $1.7 \pm 0.9 \mathrm{a}$ & $5.0 \pm 1.5 \mathrm{a}$ & $6.7 \pm 2.0 \mathrm{a}$ \\
\hline & Bifenthrin & $0.6 \pm 0.6 \mathrm{a}$ & $0.6 \pm 0.6 \mathrm{a}$ & $1.1 \pm 0.7 \mathrm{a}$ & $1.7 \pm 0.9 \mathrm{a}$ & $3.3 \pm 1.5 \mathrm{a}$ & $3.3 \pm 1.5 \mathrm{a}$ \\
\hline
\end{tabular}

Values within the same column followed by the same letter are not significantly different, Tukey's test $(p<0.01)$.

Table 4. Effects of different treatments on the mean \pm SE percentage of Maconellicoccus hirsutus nymphs that stopped feeding for six days post-treatment.

\begin{tabular}{lcccccc}
\hline \multirow{2}{*}{ Treatment } & \multicolumn{7}{c}{ \% Nymphs That Stopped Feeding } \\
\cline { 2 - 7 } & $\mathbf{1 ~ d}$ & $\mathbf{2 ~ d}$ & $\mathbf{3 ~ d}$ & $\mathbf{4} \mathbf{d}$ & $\mathbf{5 ~ d}$ & $\mathbf{6 ~ d}$ \\
\hline Non-treated & $1.1 \pm 0.7 \mathrm{a}$ & $2.2 \pm 1.3 \mathrm{a}$ & $5.0 \pm 1.9 \mathrm{a}$ & $8.9 \pm 1.7 \mathrm{a}$ & $10.6 \pm 1.5 \mathrm{a}$ & $12.8 \pm 1.7 \mathrm{a}$ \\
Water & $1.7 \pm 0.9 \mathrm{a}$ & $3.3 \pm 1.0 \mathrm{a}$ & $8.3 \pm 1.7 \mathrm{a}$ & $11.1 \pm 2.1 \mathrm{a}$ & $12.2 \pm 2.1 \mathrm{a}$ & $15.6 \pm 2.2 \mathrm{a}$ \\
Spirotetramat & $8.3 \pm 0.9 \mathrm{a}$ & $25.0 \pm 1.9 \mathrm{a}$ & $42.2 \pm 3.1 \mathrm{a}$ & $50.0 \pm 3.2 \mathrm{a}$ & $64.4 \pm 2.2 \mathrm{ab}$ & $75.6 \pm 2.2 \mathrm{~b}$ \\
Buprofezin & $8.3 \pm 0.9 \mathrm{a}$ & $19.4 \pm 2.1 \mathrm{a}$ & $41.1 \pm 3.6 \mathrm{a}$ & $48.9 \pm 3.0 \mathrm{a}$ & $56.1 \pm 3.7 \mathrm{ab}$ & $73.9 \pm 3.5 \mathrm{~b}$ \\
Sulfoxaflor & $98.3 \pm 0.9 \mathrm{~b}$ & $100.0 \mathrm{~b}$ & $100.0 \mathrm{~b}$ & $100.0 \mathrm{~b}$ & $100.0 \mathrm{~b}$ & $100.0 \mathrm{~b}$ \\
Acetamiprid & $97.3 \pm 1.3 \mathrm{~b}$ & $100.0 \mathrm{~b}$ & $100.0 \mathrm{~b}$ & $100.0 \mathrm{~b}$ & $100.0 \mathrm{~b}$ & $100.0 \mathrm{~b}$ \\
Flupyradifurone & $100.0 \mathrm{~b}$ & $100.0 \mathrm{~b}$ & $100.0 \mathrm{~b}$ & $100.0 \mathrm{~b}$ & $100.0 \mathrm{~b}$ & $100.0 \mathrm{~b}$ \\
Fenpropathrin & $100.0 \mathrm{~b}$ & $100.0 \mathrm{~b}$ & $100.0 \mathrm{~b}$ & $100.0 \mathrm{~b}$ & $100.0 \mathrm{~b}$ & $100.0 \mathrm{~b}$ \\
Bifenthrin & $100.0 \mathrm{~b}$ & $100.0 \mathrm{~b}$ & $100.0 \mathrm{~b}$ & $100.0 \mathrm{~b}$ & $100.0 \mathrm{~b}$ & $100.0 \mathrm{~b}$ \\
\hline
\end{tabular}

Values within the same column followed by the same letter are not significantly different, Fisher's Exact test $(p<0.01)$.

All tested insecticides showed zero or little effect on the mortality of adult females $(<7 \%$ mortality on day 6), and there was no significant difference among the treatments $(p<0.01)$ (Table 3). Females in all treatments (except buprofezin and spirotetramat) were unable to grip the leaf and stopped feeding. However, they were still capable of ovipositing although their oviposition was compromised by the insecticide treatments (Figure 3). The symptoms of insecticide treatments ranged from no ovisac production (spirotetramat), to long curly strands of eggs (sulfoxaflor and flupyradifurone), to dark sticky secretions with very little wax (acetamiprid), to wax production with very few eggs laid (fenpropathrin and bifenthrin). Also, treatments had a significant effect on the percentage of ovipositing females in each arena $\left(F_{8,98}=85.86, p<0.001\right)$ (Figure 4$)$. The percentages of ovipositing females were $93.9 \%$ and $90.0 \%$ in water and buprofezin treatments, respectively, which were not significantly different from non-treated control (98.9\%). Spirotetramat, sulfoxaflor, flupyradifurone, and acetamiprid had lower rates of ovipositing females ranging from $30.6 \%$ to $51.1 \%$ with no significant difference among these treatments. The lowest rate of ovipositing females was observed with bifenthrin $(10.6 \%)$ which was not statistically different from fenpropathrin (14.4\%) (Figure 4). 

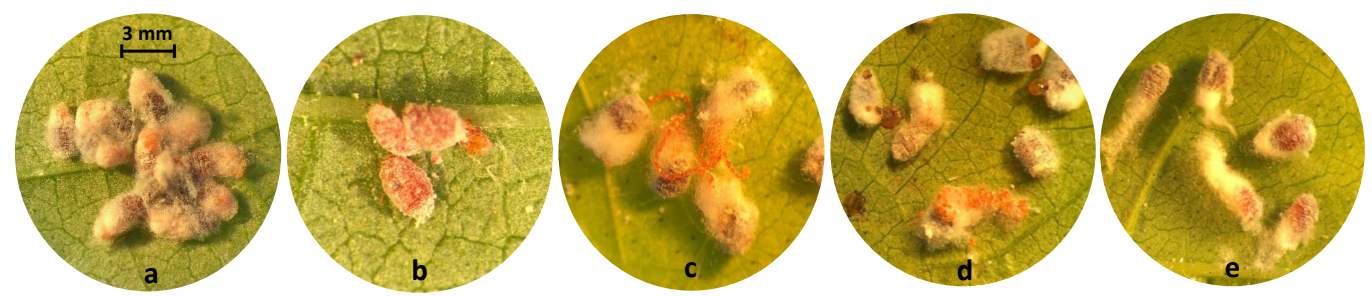

Figure 3. The side effects of different treatments on adult females of Maconellicoccus hirsutus and their oviposition behavior: (a) Normal oviposition and production of ovisacs in non-treated females and those treated with water and buprofezin. (b) Females treated with spirotetramat were not able to produce ovisacs and laid fewer scattered eggs. (c) Females treated with sulfoxaflor and flupyradifurone produced the wax needed for ovisacs but laid long curly strands of eggs not covered by the wax (d) Acetamiprid treated females produced little wax that did not cover the few eggs laid. They also made dark sticky secretions. (e) Females treated with fenpropathrin and bifenthrin produced waxy filamentous secretions of the ovisacs but only a few laid eggs.

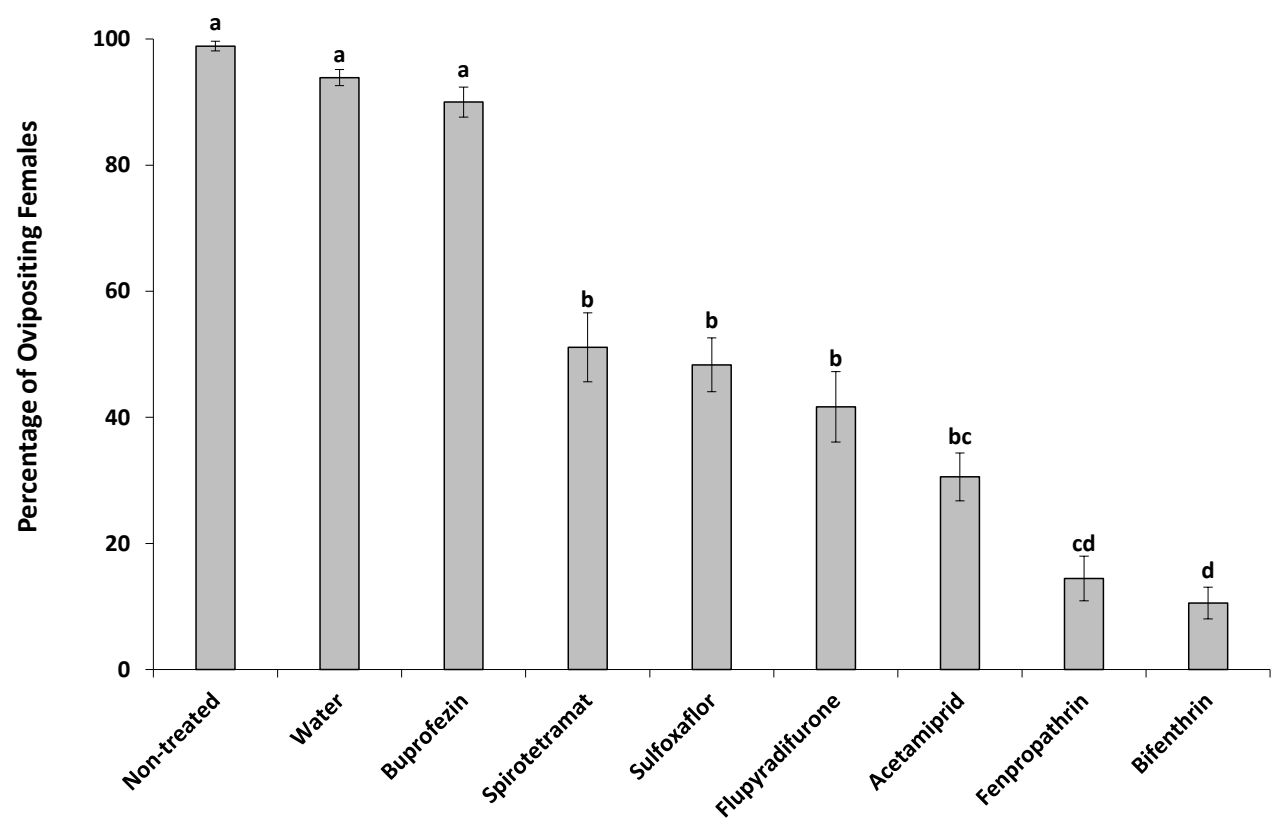

Figure 4. The relationship between different treatments and the percentage of adult females of Maconellicoccus hirsutus with successful oviposition (ANOVA summary: $F_{8,98}=76.58, p<0.001$ ). Bars with the same letter are not significantly different (Games-Howell Test, $p<0.05$ ).

\section{Discussion}

The efficacy of a broad selection of insecticides including carbamates [41,42], organophosphates [43-45], neonicotinoids [41,42,44,46], pyrethroids [41-43], and insect growth regulators [45,47] has been evaluated on pink hibiscus mealybug in the field and laboratory bioassays. However, there is no material registered for pink hibiscus mealybug suppression on dates in California, and the main objective of this study was to identify the best chemical for that purpose. Our results indicated that all of the tested insecticides were effective on this mealybug, and their effects were enhanced with an increase in exposure time.

The two pyrethroids tested, bifenthrin and fenpropathrin, effectively controlled all PHM life stages. Of the nicotinic acetylcholine receptor (nAChR) agonists tested, acetamiprid, as its label suggests, had a strong ovicidal effect and none of the treated eggs hatched. Based on our observations, the embryo developed and the dark eye spots were visible through the semitransparent chorion, but the embryo was not able to break out of the egg. This neonicotinoid also provided a high level of 
nymph mortality and significantly affected reproduction of the treated females. The second $\mathrm{nAChR}$ agonist, flupyradifurone, also resulted in high mortality of eggs, emerged crawlers, and second-instar nymphs, and it had a significant effect on the oviposition of adults. The majority of the eggs laid by the treated females were not viable, and the crawlers in those that hatched died shortly after emergence. The third tested nAChR modulator, sulfoxaflor, was slow-acting initially but provided a moderate level of nymphal control from day 4 to 6 . The lipid biosynthesis inhibitor, spirotetramat, had more activity on eggs and immature life stages of the mealybug. In addition, reproduction of adult females was reduced, and fewer eggs were laid by treated females. However, the oviposited eggs were viable and hatched. Buprofezin, the other growth regulator, did not have any effect on adult mealybugs as expected, but it was effective against the immature stages. Most of the nymphs died during molting, typical of a chitin biosynthesis inhibitor. It also adversely affected the egg hatchability of mealybugs. According to the chemical label, evidence of activity may be slower than a typical contact insecticide as treated susceptible pests may remain alive on the plant for 3-7 days. However, they stop feeding eventually leading to mortality. This is in agreement with our result that shows $50.6 \%$ mortality of nymphs at day 6 when $73.9 \%$ of the nymphs had already stopped feeding. A similar trend was obtained with the spirotetramat treatment.

The application of non-selective insecticides can result in a decrease of natural enemies, thereby bringing serious consequences in the pest population dynamics [48]. Therefore, before incorporating a chemical into the Integrated Pest Management (IPM) program of a pest, its compatibility with biological control agents that are either resident or are planned to be released should be assessed. For PHM in dates, it is essential to consider the effects of candidate chemicals on the two important parasitoids of the pink hibiscus mealybug in the Coachella Valley, A. callidus and G. indica. In addition, it is important to consider the impact on Galendromus flumenis (Chant), which is a key predator for another major pest of dates, the Banks grass mite, Oligonychus pratensis (Banks) [49,50]. Several studies have shown that bifenthrin and fenpropathrin are extremely toxic to beneficial arthropods, including the parasitoid wasps and the predatory mites [48,51-55]; therefore, the use of these pyrethroids should be carefully considered. Acetamiprid has been reported to have negative effects on several natural enemies [56-62] while being harmless to others [63-65]. Thus, the use of this material in the IPM program in dates should be evaluated further. Compared to most neonicotinoids, flupyradifurone and sulfoxaflor have a safer profile for beneficial arthropods, allowing control of pests with lower impact on natural enemies [66,67]. Spirotetramat is safe to Anagyrus sp. near pseudococci sensu Triapitsyn et al. (recently renamed Anagyrus vladimiri (Triapitsyn) [37]) as it did not show any adverse effect on the reproduction of this parasitoid species [68]. It also has been shown to be harmless to Neoseiulus californicus (McGregor) and Phytoseiulus persimilis Athias-Henriot ([63]) but had severe effects on the reproduction of Galendromus occidentalis (Nesbitt) [65] and it adversely affected all growth stages and fecundity of Neoseiulus fallacis (Garman) [69]. Furthermore, spirotetramat is known to have short residual activity, thus it may be suitable for inclusion in an IPM program on dates where we may wish to release parasitoids following insecticide treatments. Buprofezin also is safe to beneficial insects and mites. It did not have any negative effect on Anagyrus sp. near pseudococci (recently renamed $A$. vladimiri) when used for controlling citrus red mite, Panonychus citri McGregor in citrus orchards [70].

Knowledge of the differences in susceptibilities of PHM life stages to various insecticides can inform the choice of insecticides and determine the most accurate timing for applications. Based on the results obtained in this study, excellent control of PHM should be achieved with bifenthrin, fenpropathrin, flupyradifurone, acetamiprid, and sulfoxaflor. These materials caused nominal survival in nymphs emerging from treated ovisacs and rapid declines in nymphal feeding leading to high nymphal mortality. Applications should be made in the early season when eggs are just hatching, and crawlers are present. Later in the season, if more control is needed, applications of acetamiprid, fenpropathrin or bifenthrin may be helpful to reduce the number of later instar nymphs and suppress 
the reproduction of females. We suggest rotating materials with different modes of action and spectrums of activity which can delay the development of resistance.

Author Contributions: Conceptualization, T.M.P. and F.G.; Funding acquisition, Project administration, and Supervision, T.M.P.; Resources, S.A.A.; Methodology, F.G., S.A.A. and T.M.P.; Investigation, Formal analysis, Visualization, and Writing—original draft, F.G.; Writing—review \& editing, F.G., S.A.A., and T.M.P.

Funding: This research was funded, in part, by the California Date Commission and the USDA, NIFA, IR-4 Minor Crop Pest Management Program, grant number (A18-0916-S024).

Acknowledgments: We would like to thank Timothy Lewis, Shayla Hampel, Seanathan Chin, Henderson Hsu, and Colt Bellman for their assistance with squash and cotton plantings and mealybug colony maintenance. We also thank the chemical companies who kindly supplied insecticides for this study.

Conflicts of Interest: The authors declare no conflict of interest.

\section{References}

1. Green, E.E. Remarks on Indian Scale Insects (Coccidae), Part III. With a Catalogue of All Species Hitherto Recorded from the Indian Continent; CABI: Wallingford, UK, 1908; Volume 2, pp. 15-46.

2. Williams, D. A brief account of the hibiscus mealybug Maconellicoccus hirsutus (Hemiptera: Pseudococcidae), a pest of agriculture and horticulture, with descriptions of two related species from southern Asia. Bull. Entomol. Res. 1996, 86, 617-628. [CrossRef]

3. Hall, W.J. The Hibiscus Mealy Bug (Phenacoccus Hirsutus, Green) in Egypt in 1925 with Notes on the Introduction of Cryptolœmus Montrouzieri, Muls; Government Press: Dublin, Ireland, 1926.

4. Williams, D. The identity and distribution of the genus Maconellicoccus Ezzat (Hemiptera: Pseudococcidae) in Africa. Bull. Entomol. Res. 1986, 76, 351-357. [CrossRef]

5. Matile-Ferrero, D.; Etienne, J.; Tiego, G. Introduction of two important pests to French Guiana: Maconellicoccus hirsutus and Paracoccus marginatus (Hem., Coccoidea, Pseudococcidae). Bull. Soc. Entomol. Fr. 2000, 105, 485-486.

6. Germain, J. Four species of invasive scale insects new for Reunion Island (Hemiptera, Coccoidea). Bull. Soc. Entomol. Fr. 2013, 118, 509-511.

7. Halima-Kamel, M.B.; Germain, J.; Mdellel, L. First records of two mealybugs, Maconellicoccus hirsutus (Green) and Phenacoccus peruvianus Granara de Willink, in Tunisia and the North of Africa. EPPO Bull. 2015, 45, 139-143. [CrossRef]

8. Marotta, S.; Harten, A.V.; Mahyoub, M. Mealybugs found on agricultural crops in Yemen. Boll. Zool. Agrar. Bachic. 2001, 33, 233-238.

9. Spodek, M.; Watson, G.; Mendel, Z. The pink hibiscus mealybug, Maconellicoccus hirsutus (Green) (Hemiptera: Coccomorpha: Pseudococcidae), a new threat to Israel's agriculture and horticulture. EPPO Bull. 2016, 46, 311-312. [CrossRef]

10. Goolsby, J.A.; Kirk, A.A.; Meyerdirk, D.E. Seasonal phenology and natural enemies of Maconellicoccus hirsutus (Hemiptera: Pseudococcidae) in Australia. Fla. Entomol. 2002, 85, 494-498. [CrossRef]

11. Chang, L.W.; Miller, C.E. Pathway Risk Assessment: Pink Mealybug from the Caribbean; Planning and Risk Analysis Systems, Policy and Program Development, Animal and Plant Health Inspection Service, US Department of Agriculture: Washington, DC, USA, 1996.

12. Sagarra, L.; Peterkin, D. Invasion of the Carribean by the hibiscus mealybug, Maconellicoccus hirsutus Green [Homoptera: Pseudococcidae]. Phytoprotection 1999, 80, 103-113. [CrossRef]

13. Kairo, M.T.; Pollard, G.V.; Peterkin, D.D.; Lopez, V.F. Biological control of the hibiscus mealybug, Maconellicoccus hirsutus Green (Hemiptera: Pseudococcidae) in the Caribbean. Integr. Pest Manag. Rev. 2000, 5, 241-254. [CrossRef]

14. Cermeli, M.; Morales Valles, P.; Godoy, F.; Romero, R.; Cárdenas, O.; de Sanidad Agropecuaria, S.A. Precence of the hibiscus pink mealybug Maconellicoccus hirsutus (Green) (Hemiptera: Pseudococcidae) in Venezuela. Entomotrópica 2002. Available online: http://agris.fao.org/agris-search/search.do?recordID= VE2007400217 (accessed on 16 January 2019). 
15. Kondo, T.; Gullan, P.; Portilla, A.A.R. 0265. Report of new invasive scale insects (Hemiptera: Coccoidea), Crypticerya multicicatrices Kondo and Unruh (Monophlebidae) and Maconellicoccus hirsutus (Green)(Pseudococcidae), on the islands of San Andres and Providencia, Colombia, with an updated taxonomic key to iceryine scale insects of South America. Insecta Mundi 2012, 1-17. Available online: https: / / digitalcommons.unl.edu/cgi/viewcontent.cgi?article=1775\&context=insectamundi (accessed on 16 January 2019).

16. Marsaro Júnior, A.; Peronti, A.; Penteado-Dias, A.; Morais, E.; Pereira, P.d.S. First report of Maconellicoccus hirsutus (Green, 1908) (Hemiptera: Coccoidea: Pseudococcidae) and the associated parasitoid Anagyrus kamali Moursi, 1948 (Hymenoptera: Encyrtidae), in Brazil. Braz. J. Biol. 2013, 73, 413-418. [CrossRef] [PubMed]

17. Broglio, S.; Cordero, E.; dos Santos, J.; Micheletti, L. Record of pink hibiscus mealybug infesting fruit species in Maceió, Alagoas, Brazil. Rev. Caatinga 2015, 28, 242-248.

18. Villatoro-Moreno, H.; Cisneros, J.; Gómez, J.; Infante, F.; Castillo, A. Mealybugs (Hemiptera: Pseudococcidae) Associated with Rambutan (Nephelium lappaceum L.) in Chiapas, Mexico. J. Kans. Entomol. Soc. 2016, 89, 289-296. [CrossRef]

19. Beardsley, J. Notes and exhibitions. Proc. Hawaii. Entomol. Soc. 1985, 25, 27-28.

20. Reddy, G.; Muniappan, R.; Cruz, Z.; Naz, F.; Bamba, J.; Tenorio, J. Present status of Maconellicoccus hirsutus (Hemiptera: Pseudococcidae) in the Mariana Islands and its control by two fortuitously introduced natural enemies. J. Econ. Entomol. 2009, 102, 1431-1439. [CrossRef] [PubMed]

21. Michaud, J.; Evans, G. Current status of pink hibiscus mealybug in Puerto Rico including a key to parasitoid species. Fla. Entomol. 2000, 83, 97-101. [CrossRef]

22. Carter-Lane, S.; Redding, J. Exotic Parasitic Wasps to Attack Invasive Mealybug in California; USDA, APHIS: Washington, DC, USA, 1999.

23. Hoy, M.; Hamon, A.; Nguyen, R. Pink Hibiscus Mealybug, Maconellicoccus hirsutus (Green); EENY-029; University of Florida University IFAS Extensión: Gainesville, FL, USA, 2002.

24. Meyerdirk, D. Status Report on the Pink Hibiscus Biological Control Program; USDA, APHIS, PPQ: Riverdale, MD, USA, 1997.

25. [NAPIS] National Agricultural Pest Information System. Pest Tracker. 2017. Available online: https: / / napis.ceris.purdue.edu/home (accessed on 16 January 2019).

26. Mani, M. A review of the pink mealybug-Maconellicoccus hirsutus (Green). Int. J. Trop. Insect Sci. 1989, 10, 157-167. [CrossRef]

27. Garland, J. Pest Risk Assessment of the Pink Mealybug Maconellicoccus hirsutus (Green), with Particular Reference to Canadian Greenhouses; PRA 96e21; Canadian Food Inspection Agency: Ottawa, ON, Canada, 1998.

28. Pasiecznik, N.; Smith, I.; Watson, G.; Brunt, A.; Ritchie, B.; Charles, L. CABI/EPPO distribution maps of plant pests and plant diseases and their important role in plant quarantine. EPPO Bull. 2005, 35, 1-7. [CrossRef]

29. Hall, W.J. The hibiscus mealy bug (Phenacoccus hirsutus, Green). In Bulletin Ministry of Agriculture Egypt Technical and Scientific Service Entomological Section; Government Press: Dublin, Ireland, 1921; Volume 17, pp. 1-28.

30. Ghose, S. Morpho-histological changes in some economic plants due to the infestation of mealy-bug, Maconellicoccus hirsutus (Green)(Hemiptera: Pseudococcidae). Indian J. Agric. Sci. 1972, 42, 329-334.

31. Stibick, J. New Pest Response Guidelines-Pink Hibiscus Mealybug, Maconellicoccus hirsutus; US Department of Agriculture, Animal and Plant Health Inspection Service: Riverdale, MD, USA, 1997.

32. Zhang, A.; Amalin, D.; Shirali, S.; Serrano, M.S.; Franqui, R.A.; Oliver, J.E.; Klun, J.A.; Aldrich, J.R.; Meyerdirk, D.E.; Lapointe, S.L. Sex pheromone of the pink hibiscus mealybug, Maconellicoccus hirsutus, contains an unusual cyclobutanoid monoterpene. Proc. Natl. Acad. Sci. USA 2004, 101, 9601-9606. [CrossRef] [PubMed]

33. Mani, M.; Shivaraju, C. Mealybugs and Their Management in Agricultural and Horticultural Crops; Springer: Berlin, Germany, 2016.

34. Moffitt, L. Economic Risk to United States Agriculture of Pink Hibiscus Mealybug Invasion; A Report to the United States Department of Agriculture, Animal and Plant Health Inspection Service; USDA: Washington, DC, USA, 1999. 
35. Ranjan, R. Economic impacts of pink hibiscus mealybug in Florida and the United States. Stoch. Environ. Res. Risk Assess. 2006, 20, 353. [CrossRef]

36. Roltsch, W.J.; Meyerdirk, D.E.; Warkentin, R.; Andress, E.R.; Carrera, K. Classical biological control of the pink hibiscus mealybug, Maconellicoccus hirsutus (Green), in southern California. Biol. Control 2006, 37, 155-166. [CrossRef]

37. Andreason, S.A.; Triapitsyn, S.V.; Perring, T.M. Untangling the Anagyrus pseudococci species complex (Hymenoptera: Encyrtidae), parasitoids of worldwide importance for biological control of mealybugs (Hemiptera: Pseudococcidae): Genetic data corroborates separation of two new, previously misidentified species. Biol. Control 2019, 129, 65-82.

38. Bliss, D.E.; Lindgren, D.L. The Use of Thiomate '19'on Dates and Its Effect on Fruit Spoilage; CABI: Wallingford, UK, 1947; pp. 5-9.

39. Perring, T.M.; Nay, J.E. Evaluation of bunch protectors for preventing insect infestation and preserving yield and fruit quality of dates, Phoenix dactylifera L. J. Econ. Entomol. 2015, 108, 654-661. [CrossRef]

40. R Core Team. R: A Language and Environment for Statistical Computing; R Foundation for Statistical Computing: Vienna, Austria, 2018.

41. Fatima, S.; Hussain, M.; Malik, M.F.; Noureen, N.; ul Ane, N.; Abbas, Z. Field efficacy of some insecticides against hibiscus mealybug, Maconellicoccus hirsutus (Hemiptera: Pseudococcidae). Population 2016, 10, 100.

42. Fatima, S.; Hussain, M.; Shafqat, S.; Faheem Malik, M.; Abbas, Z.; Noureen, N.; Ane, N. Laboratory Evaluation of Different Insecticides against Hibiscus Mealybug, Maconellicoccus hirsutus (Hemiptera: Pseudococcidae). Scientifica 2016, 2016, 9312013. [CrossRef]

43. Anand, P.; Ayub, K. The effect of five insecticides on Maconellicoccus hirsutus (Green)(Homoptera: Pseudococcidae) and its natural enemies Anagyrus kamali Moursi (Hymenoptera: Encyrtidae), and Cryptolaemus montrouzieri Mulsant and Scymnus coccivora Aiyar (Coleoptera: Coccinellidae). Int. Pest Control 2000, 42, 170-173.

44. Sunitha, N.; Jagginavar, S.; Biradar, A. Bioefficacy botanicals and newer insecticides against grape vine mealy bug, Maconellicoccus hirsutus (Green). Karnataka J. Agric. Sci. 2009, 22, 710-711.

45. Aida, H.M.; Saber, F.; Ahmed, H.; Sayed, A. Efficiency of certain insecticides on the population (s) of the pink hibiscus mealybug Maconellicoccus hirsutus(Green) and their natural enemies under the field condition in Ismailia governorate. Egypt. Acad. J. Biol. Sci. 2010, 2, 11-17.

46. Castle, S.; Prabhaker, N. Field evaluation of two systemic neonicotinoid insecticides against pink hibiscus mealybug (Maconellicoccus hirsutus (Green)) on mulberry trees. J. Pest Sci. 2011, 84, 363-371. [CrossRef]

47. Jacobsen, C.M.; Hara, A.H. Field and postharvest treatments against the pink hibiscus mealybug, Maconellicoccus hirsutus (Green)(Homoptera: Pseudococcidae). Plant Environ. Prot. Sci. 2002. Available online: https: / / esa.confex.com/esa/2002/techprogram/paper_6895.htm (accessed on 16 January 2019).

48. Stanley, J.; Preetha, G. Pesticide Toxicity to Parasitoids: Exposure, Toxicity and Risk Assessment Methodologies. In Pesticide Toxicity to Non-Target Organisms; Springer: Berlin, Germany, 2016; pp. 99-152.

49. Ganjisaffar, F.; Perring, T.M. Prey stage preference and functional response of the predatory mite Galendromus flumenis to Oligonychus pratensis. Biol. Control 2015, 82, 40-45. [CrossRef]

50. Ganjisaffar, F.; Perring, T.M. A life table analysis to evaluate biological control of banks grass mite using the predatory mite, Galendromus flumenis (Acari: Phytoseiidae). Syst. Appl. Acarol. 2017, 22, 7-13. [CrossRef]

51. Hamby, K.A.; Alifano, J.A.; Zalom, F.G. Total effects of contact and residual exposure of bifenthrin and $\lambda$-cyhalothrin on the predatory mite Galendromus occidentalis (Acari: Phytoseiidae). Exp. Appl. Acarol. 2013, 61, 183-193. [CrossRef]

52. de Morais, M.R.; Zanardi, O.Z.; Rugno, G.R.; Yamamoto, P.T. Impact of five insecticides used to control citrus pests on the parasitoid Ageniaspis citricola Longvinovskaya (Hymenoptera: Encyrtidae). Ecotoxicology 2016, 25, 1011-1020. [CrossRef] [PubMed]

53. Khajuria, D.; Sharma, J. Bio-efficacy of various acaricides against the phytophagous mites on apple and their sensitivity to the phytoseiid mites. Pest Manag. Econ. Zool. 2010, 18, 116-121.

54. Alzoubi, S.; Cobanoglu, S. Toxicity of some pesticides against Tetranychus urticae and its predatory mites under laboratory conditions. Am. Eurasian J. Agric. Environ. Sci. 2008, 3, 30-37.

55. Kavya, M.; Srinivasa, N.; Vidyashree, A.; Ravi, G. Bioefficacy of newer acaricides against two spotted spider mite, Tetranychus urticae and phytoseiid predator, Neoseiulus longispinosus on brinjal under field condition. Plant Arch. 2015, 15, 493-497. 
56. Grafton-Cardwell, E.E.; Gu, P. Conserving vedalia beetle, Rodolia cardinalis (Mulsant) (Coleoptera: Coccinellidae), in citrus: A continuing challenge as new insecticides gain registration. J. Econ. Entomol. 2003, 96, 1388-1398. [CrossRef] [PubMed]

57. Cloyd, R.A.; Dickinson, A. Effect of insecticides on mealybug destroyer (Coleoptera: Coccinellidae) and parasitoid Leptomastix dactylopii (Hymenoptera: Encyrtidae), natural enemies of citrus mealybug (Homoptera: Pseudococcidae). J. Econ. Entomol. 2006, 99, 1596-1604. [CrossRef]

58. Naranjo, S.E.; Akey, D.H. Conservation of natural enemies in cotton: comparative selectivity of acetamiprid in the management of Bemisia tabaci. Pest Manag. Sci. 2005, 61, 555-566. [CrossRef]

59. Laurin, M.C.; Bostanian, N.J. Laboratory studies to elucidate the residual toxicity of eight insecticides to Anystis baccarum (Acari: Anystidae). J. Econ. Entomol. 2007, 100, 1210-1214. [CrossRef] [PubMed]

60. Cheng, S.; Lin, R.; Lin, T.; You, Y.; Zeng, Z.; Zhou, X.; Zhou, Y.; Jiang, H.; Wei, H.; Fu, J.; et al. Effects of acetamiprid on life cycle development of predatory mite Amblyseius cucumeris (Acari: Phytoseiidae) after contact exposure. Chemosphere 2018, 210, 889-895. [CrossRef] [PubMed]

61. Barbar, Z. Evaluation of three pesticides against phytophagous mites and their impact on phytoseiid predators in an eggplant open-field. Acarologia 2017, 57, 529-539.

62. Poletti, M.; Maia, A.; Omoto, C. Toxicity of neonicotinoid insecticides to Neoseiulus californicus and Phytoseiulus macropilis (Acari: Phytoseiidae) and their impact on functional response to Tetranychus urticae (Acari: Tetranychidae). Biol. Control 2007, 40, 30-36. [CrossRef]

63. Argolo, P.S.; Jacas, J.A.; Urbaneja, A. Comparative toxicity of pesticides in three phytoseiid mites with different life-style occurring in citrus: Euseius stipulatus, Neoseiulus californicus and Phytoseiulus persimilis. Exp. Appl. Acarol. 2014, 62, 33-46. [CrossRef]

64. Villanueva, R.T.; Walgenbach, J.F. Development, oviposition, and mortality of Neoseiulus fallacis (Acari: Phytoseiidae) in response to reduced-risk insecticides. J. Econ. Entomol. 2005, 98, 2114-2120. [CrossRef]

65. Beers, E.H.; Schmidt, R.A. Impacts of orchard pesticides on Galendromus occidentalis: Lethal and sublethal effects. Crop Prot. 2014, 56, 16-24. [CrossRef]

66. Campbell, J.W.; Cabrera, A.R.; Stanley-Stahr, C.; Ellis, J.D. An evaluation of the honey bee (Hymenoptera: Apidae) safety profile of a new systemic insecticide, flupyradifurone, under field conditions in Florida. J. Econ. Entomol. 2016, 109, 1967-1972. [CrossRef] [PubMed]

67. Tran, A.K.; Alves, T.M.; Koch, R.L. Potential for sulfoxaflor to improve conservation biological control of Aphis glycines (Hemiptera: Aphididae) in soybean. J. Econ. Entomol. 2016, 109, 2105-2114. [CrossRef] [PubMed]

68. Mansour, R.; Suma, P.; Mazzeo, G.; Lebdi, K.G.; Russo, A. Evaluating side effects of newer insecticides on the vine mealybug parasitoid Anagyrus sp. near pseudococci, with implications for integrated pest management in vineyards. Phytoparasitica 2011, 39, 369-376. [CrossRef]

69. Venkatesan, T.; Jalali, S.; Ramya, S.; Prathibha, M. Insecticide resistance and its management in mealybugs. In Mealybugs and Their Management in Agricultural and Horticultural Crops; Springer: Berlin, Germany, 2016; pp. 223-229.

70. Suma, P.; Mazzeo, G. Laboratory evaluation of pesticide secondary effects on Anagyrus sp. nov. near pseudococci, parasitoid of the citrus mealybug Planococcus citri. IOBC/WPRS Bull. 2008, 38, 99-103.

(C) 2019 by the authors. Licensee MDPI, Basel, Switzerland. This article is an open access article distributed under the terms and conditions of the Creative Commons Attribution (CC BY) license (http://creativecommons.org/licenses/by/4.0/). 